\title{
Overview of early childhood care and education in Malaysia
}

\author{
BAHBIBI RAHMATULLAH ${ }^{1,2 *}$ (D), NORSHAKILA MUHAMAD RAWAI ${ }^{1}$, \\ SUZANI MOHAMAD SAMURI ${ }^{1,2}$ and SOPIA MD YASSIN ${ }^{1,3}$
}

\footnotetext{
${ }^{1}$ National Child Development Research Centre (NCDRC), Sultan Idris Education University, Perak, Malaysia

${ }^{2}$ Data Intelligence and Knowledge Management (DILIGENT), Faculty of Arts, Computing and Creative Industry, Sultan Idris Education University, Perak, Malaysia

${ }^{3}$ Faculty of Social Sciences and Leisure Management, School of Education, Taylor's University, Selangor, Malaysia
}

\section{THEMATIC ARTICLE}

Received: May 4, 2021 • Accepted: June 17, 2021

Published online: October 25, 2021

(C) 2021 The Author(s)

\section{ABSTRACT}

Early childhood care and education (ECCE) is commonly understood in Malaysia as providing care and education for young children from the age of newborn until about six years old, before they enter formal elementary education. Various curriculum and teaching approaches were developed to enhance children's learning experiences based on their needs, age, and ability to support all three main developmental aspects: cognitive (language development and problem-solving skills), physical (development of gross and fine motor skills), and social-emotional (interaction with others). This paper will provide an overview of Malaysia's ECCE from its early implementation until today based on literature review of related research conducted in Malaysia. The definition of ECCE in Malaysia, its history and development, ECCE providers and type of institutions, current ECCE curriculum, and ECCE related acts in Malaysia are presented. In addition, the challenges faced, its consequences, and future course of ECCE in Malaysia are also discussed. It is envisaged that this article would be a platform for the relevant stakeholders worldwide to gain an insight on the Malaysian ECCE, serve as a benchmark and act as a reference for their respective ECCE settings.

\section{KEYWORDS}

early childhood, care and education, child development, childcare, nursery, preschools, kindergartens, Malaysia

\footnotetext{
*Corresponding author. E-mail: bahbibi@fskik.upsi.edu.my
} 


\section{INTRODUCTION}

The early years is a time of extraordinary growth with significant brain development and neural structuring, which occurs from conception to age five. The first years of life's sensitive developmental period establish life-long social participation and productivity (Shonkoff \& Phillips, 2000). A child's developing brain architecture provides either a strong or weak foundation for future learning, behavior, and health are determined by the experiences children had at this time (Center on the Developing Child, 2007).

Previous lack of attention given to early childhood was of concern to the United Nations Committee on the Rights of the Child. It was made clear that all children, including the very youngest, are holders of all rights enshrined in the UNCRC and as such should be "recognized as active members of families, communities and societies, with their concerns, interests, and points of view" in its General Comment "Implementing Child Rights in Early Childhood" (United Nations Committee on the Rights of the Child, 2005, p. 11). In parallel, the World Conference on Education for All (EFA) emphasized an urgent priority to ensure access to and improve the quality of education for all children (UNESCO, 2007).

As knowledge accumulates about the importance of early childhood development for longterm outcomes, so does the growing focus on early childhood education. Early childhood education in this paper refers to efforts in developing young children's cognitive and non-cognitive skills in a premise such as a preschool (interchangeably known as kindergarten in Malaysia) or daycare center (or also known as nursery in Malaysia). There is a vast body of evidence in research with consistent findings that demonstrate better performance on later outcomes in attainment, crime, health, and productivity of children who attended ECCE (Heckman, Stixrud, \& Urzua, 2006). These have prompted significant enthusiasm on the positive effects of attending ECCE (Berlinski, Galiani, \& Gertler, 2009; Black et al., 2017; Felfe \& Lalive, 2018). However, it is the quality of the ECCE provided that builds the foundation and paves the way for children to succeed in their future course of life (Berlinski, Galiani, \& Manacorda, 2008; Havnes \& Mogstad, 2011; Murnane \& Ganimian, 2014).

In Malaysia, the main purpose of the establishment of a nursery was to provide a conducive space and environment for supporting children's growth from to zero to four years old by providing developmentally appropriate learning experiences. Meanwhile, the preschool education offers informal educational programs for children between four to six years old to foster a positive school-readiness attitude in preparation for entry into formal schooling at the elementary level (Institut Pendidikan Guru Malaysia, 2018; Mofrad, 2012).

This article is intended to provide current information from vast academic literatures for global stakeholders (including but not limited to researchers, government and non-governmental organisations, teachers, and parents) interested in learning more about ECCE settings in Malaysia, as it could be used as a guideline about any ECCE-related information or decision.

\section{HISTORY AND DEVELOPMENT OF MALAYSIAN ECCE}

Malaysia's preschool education program was introduced in the 1950s and has proliferated since the 1960s (Imran, Faizul, Khadijah, Rizawati, \& Wan, 2010; Institut Pendidikan Guru Malaysia, 2018). According to Hussin (1993), preschool education in the 1950s focused on children from 
the upper income classes due to the high service fees charged. Concurrently, there were preschools sponsored and managed by Christian organizations that operate churches (Chiam, 2008). However, this has led to ECCE opportunities being limited to only the rural areas in Malaysia.

The first public preschool in Malaysia was established in the early 1970s by the Department of Community Development (KEMAS) under the Ministry of Rural Development's responsibilities. Subsequently, in the late 1970s, preschools in the urban areas where there are 'Rukun Tetangga' (a friendly neighborhood scheme) was set up by the Department of National Unity and Integration. These preschools are commonly known as TABIKA PERPADUAN. The main characteristic of TABIKA PERPADUAN is the encouragement of enrollment of children from various races in Malaysia. Consequently, in 2013, a total of 8307 preschools by KEMAS (commonly known as the TABIKA KEMAS), and 1496 TABIKA PERPADUAN were established (Mamat, 2019; Mustafa \& Azman, 2013).

In line with the Malaysian government's desire to provide educational opportunities for all, the private sector also participated in the effort. The 1980s saw a change in the ECCE environment whereby the private sector also offered preschool educational opportunities as an alternative to parents who were ineligible from enrolling their children in government preschools. In addition, these private preschools operating throughout the country do not only provide educational opportunities to Malaysians but also international citizens. These private preschools are regarded as private educational institutions because they are non-governmental and are fully funded by the private sector (Majzub \& Rashid, 2012; Qin \& Nor, 2018).

According to Majzub (2003), a study conducted by the Ministry of Education of Malaysia estimated that 490,700 children under five years of age should receive preschool education in 1991. However, only about $47 \%$ of the total number of these children had access to preschool education while about $53 \%$ did not have the opportunity to attend preschool classes. As a result, in early January 1992, MOE developed preschools in the form of a pilot project called an 'annex' to an existing primary school known as 'prasekolah.' Thereupon, in 1996, the preschool education was incorporated into the national education system. The accomplishments so far indicated that the Malaysian government recognizes preschool education as the basis for primary school education. The MOE preschool project was later extended to the entire nation in 2003. Among the agencies involved in the implementation of this preschool education program are the Department of Community Development (KEMAS), Department of National Unity and National Integration (PERPADUAN), Islamic Religious Affairs Department, Federal Land Development Authority (FELDA), Rubber Industry Smallholders Development Authority (RISDA), Federal Land Consolidation and Recovery Board (FELCRA), Sabah Foundation and Ministry of Education Malaysia (MOE) (Hussin, 1993). In addition, other providers of preschool education in Malaysia include the State Religious Department (Jabatan Agama Islam Negeri JAIN), and Muslim Youth Movement of Malaysia (Angkatan Belia Islam Malaysia ABIM) (Mustafa \& Azman, 2013).

While preschools started earlier in the 1950s, child care services were available only in the late 1970 s when more than $31 \%$ of women joined the workforce and extended families were not able to assist with the caring of children (Chiam, 2008). For professional parents in the urban areas at that time, British-trained primary school teachers and nurses were mainly responsible for setting up institutional childcare centers, also known as nurseries. In addition, home-based operators also offered childcare services in their homes to accommodate young children's needs. 
A third type of childcare service are the ones provided by the estate management in plantation areas as stipulated by the Workers' Minimum Standards of Housing and Amenities Act 1990 (Act 446).

Realizing the need for setting minimum standards and regulations for childcare services and in the wake of the report on a survey on childcare by the Social Welfare Services Department in 1983, the government passed the Child Care Centre Act (Act 308) in 1984. This Act requires all institution-based childcare centers to be registered, except for home-based childcare centers with less than four children. However, these centers with more than four and a maximum of nine children would have to be registered. However, this Act did not cover estate childcare centers under the Ministry of Human Resource. Apart from this the Director-General of the Social Welfare Department was empowered by the Act to ensure the children and personnel's health and well-being. At the same time, the Minister was given the authority to generate regulations pertaining to, for instance, registration, qualification, issuing certificates of child-minders, and health and nutrition care of the children in the center (The Commissioner of Law Revision Malaysia, 1984).

A current and latest initiative known as the National Children's PERMATA Center (Pusat Anak PERMATA Negara) was established as an ECCE provider under the Prime Minister's office. This PERMATA Program is an ECCE program unique for children aged four and below. Themed 'Every Child a Jewel' ('Setiap Anak Permata'), the PERMATA Negara pilot project was launched in 2006. In this program, the childcare center utilizes the PERMATA modules in their care and learning process (Ayob, 2011). The program underwent a two-year pilot test, from 2006 to 2007, involving five National PERMATA Centers in four states namely, Selangor, Putrajaya, Pahang, and Penang. In 2008, the program was expanded nationwide. At the end of 2009, the centers, departments and ministries or agencies involved in the program were the National PERMATA Children Center (Prime Minister's Department), TASKA PERMATA KEMAS (Department of Community Development, Ministry of Rural and Regional Development), TASKA PERMATA PERPADUAN (Department of National Unity and Integration JPNIN), Community and Workplace Childcare Centers (Ministry of Women, Family and Community Development) and the PERMATA Family Childcare Centers (Terengganu Family Development Foundation) (Ayob, 2011; Kosnin et al., 2018). Presently, there are 90 National PERMATA Centers throughout Malaysia.

\section{TYPES OF ECCE INSTITUTIONS IN MALAYSIA}

Basically, the Ministry of Women, Family and Community Development (MWFCD) is responsible for the approval and establishment of childcare centers in the country, while the Department of Social Welfare (or Jabatan Kebajikan Masyarakat - JKM) serves as the primary regulator and coordinator of ECCE programs. JKM is responsible for the registration, inspection, and enforcement of childcare centers, and matters related to it to ensure the well-being, safety, and overall development of children are prioritized (Imran et al., 2010). The kindergarten or preschool for five to six year old children is regulated by the Ministry of Education (MOE). Hence the ECCE programs in Malaysia are mainly defined by these two institutions.

1. Childcare centers (also known as nurseries or TASKA) 
In Malaysia, a registered childcare center is identified as any premise that offers care on a fee basis for four or more children under the age of four years from more than one household. Accordingly, childcare centers in Malaysia are classified by JKM into four types:

i. Community childcare centers

These childcare centers are established based on initiatives by the community to provide quality, more accessible, and affordable services to low-income families in urban and rural areas. The center takes in ten or more children and receives assistance from the Federal or State Government.

ii. Workplace childcare centers

This type of childcare is founded on the employers' initiative for their employees' welfare and provides care for ten or more children. The government provides incentives for the renovation and furnishing of these centers which are set up within government offices. With the private sector, as a stimulus to provide childcare facilities at the workplace for their employees, a $10 \%$ tax reduction for ten years of operation was offered.

iii. Institution-based childcare centers

This category of childcare is initiated by both the private sector and Non-Governmental Organizations (NGOs) in providing care for ten or more children.

iv. Home-based childcare centers

This group of registered childcare centers operate in an owner's residence and are allowed to care for four to nine children. However, home-based centers with less than four children are not required to register with JKM.

2. Preschools (also known as kindergartens or TADIKA)

The KEMAS department under the Ministry of Rural and Regional Development, JPNIN department, and MOE are among the primary providers of public kindergartens for children aged between four to six years old in Malaysia. Additionally, a considerable number of preschools are being operated by the State Religious Departments, NGOs, and the private sector (Qin \& Nor, 2018). The registration and curriculum of such centers are bounded by the Education Act of 1996. It is worth noting that the government fully funds the public preschools managed by the relevant ministries. Preschools in Malaysia commonly fall under the following categories of operators:

i. MOE Preschools

These preschools are set up by the MOE to increase accessibility to preschool education for low-income families in suburban, rural, and remote areas. The preschools employ teachers who are trained and qualified in the field of preschool education. 


\section{ii. KEMAS Preschools}

The preschools founded by KEMAS under the Ministry of Rural and Regional Development, mainly serves children from families with low income.

iii. PERPADUAN Preschools

JPNIN's established preschools specifically in areas with a 'Skim Rukun Tetangga' (a 'friendly neighborhood scheme').

iv. Preschools Operated by Private Sectors and NGOs

This category of private preschools complements the government's efforts to deliver quality education to children aged four to six. Furthermore, it is compulsory for these preschools to adopt the National Preschool Curriculum as stipulated by the 1996 National Education Act. However, some of these preschools also offer "imported models" and commercialized child learning programs that are expensive and accommodates for working parents' convenience (Majzub \& Rashid, 2012; Qin \& Nor, 2018).

The various types of ECCE centers discussed are among various initiatives to provide ECCE programs, especially by the government, in making preschools more accessible to children from low-income backgrounds and those living in rural areas. Such services provide a solid foundation for the healthy growth and development of children besides strengthening their transition into primary school education. The government also allocated substantial funding for ECCE every year (Kementerian Pendidikan Malaysia, 2013).

\section{ECCE CURRICULUM}

An ECCE program ought to suit a child's developmental level to stimulate thinking, develop positive attitudes and behaviors, and enhance fitness and health towards optimal potency (Pope, 2017). Therefore, the ECCE curriculum in use, need to focus on developing children in a holistic, balanced, and integrated manner. Flexible learning approaches, a comfortable, safe, and cheerful learning environment, encouraging curiosity, and a sense of exploration offer new experiences to achieve the desired outcomes for children.

In Malaysia, there are two national level early childhood curriculum that are specifically developed for the two types of ECCE institutions, as previously described, namely nursery (TASKA) and kindergarten (TADIKA or TABIKA) for children ages zero to six years old. The two national curriculums are:

i. PERMATA National Curriculum for children aged 0-4 years old

ii. National Preschool Standard Curriculum (NPSC) for children aged $4+$ to $5+$ years.

Although these are stipulated as the national curriculum, the implementation is often flexible. For instance, in the adoption of these curriculum by KEMAS, JAIN, PERPADUAN, and the private sector, it is reflected in the variety of approaches used, lesson planning practices and 
types of interaction that occur during activities (Imran et al., 2010). Sections (I) and (II) below describe the main components of the curriculum.

\section{PERMATA National Curriculum}

The PERMATA National Curriculum aspires to provide ECCE experiences for the holistic development of children ages $0-4$ years old, by taking into account children's diverse potentials based on the principles of learning through play (Bahagian PERMATA, 2013). This curriculum is also in accordance with Malaysia's National Philosophy of Education emphasizing five key aspects to ensure an encompassing program for young children involving:

- Active interaction and communication

- Stimulation of mind and literacy

- Empowering children

- Independent learning

- Monitoring children's abilities and potentials

- Learning through play

The contents of the curriculum were formulated to address six key areas of learning and development which include:

- Development of Early Mathematics and Logic Thinking

- Development of Senses and Understanding of the Environment

- Development of Language, Communication and Early Literacy

- Development of Creativity and Aesthetics

- Physical Development

- Personality, Socio-Emotional and Spiritual Development

With the purpose of assuring the quality in the implementation of the PERMATA National Curriculum, only educators who are trained and qualified in ECCE are appointed. These educators need explicit knowledge, training, and understanding in ECCE to translate the curriculum and use appropriate resources and infrastructure facilities that are able to fulfil children's developmental needs to generate meaningful learning (Kosnin et al., 2018).

\section{National Preschool Standard Curriculum (NPSC)}

The NPSC was formulated to standardize the curriculum, facilities, and training of teachers in the public sector and private preschool centers to address the requirements of the Education Act 1996 (Bahagian Pembangunan Kurikulum, 2017; Hussin, 1993). The curriculum was piloted in 100 schools across the country in 2002 to ascertain the adequacy of the curriculum. Consequently, in 2003, the NPSC was rolled-out throughout Malaysia. Since the first enforcement of the curriculum in 2010, it was revised in 2016 in tandem with the Malaysia Education Blueprint 2013-2025 and current educational needs (Kementerian Pendidikan Malaysia, 2013). In terms of content, the NPSC is built on six pillars, namely:

- Communication

- Science and Technology

- Spiritual, Attitude, and Values

- Humanity 
- Self-Appearance

- Physical and Aesthetic Development

These six pillars are the domains that support each other and are integrated with critical, creative, and innovative thinking. The objective is to produce human capital that embraces good moral values, are knowledgeable, practice critical thinking, and proffer creative and innovative ideas (Kasim, 2014; Rahman \& Noor, 2018).

Through the Education Act 1996 (2006), preschool education was included in the national education system. It also establishes that all preschools, regardless of their types, private or government-owned, must adhere to the national statutory preschool curriculum, i.e., the NPSC. The aim is to nurture children's potential in a comprehensive manner across all areas, including physical, spiritual, social, and intellectual development, in a safe and conducive learning environment through fun, creative, and meaningful activities. This is in line with the National Education Philosophy, which aims to produce holistic individuals to advance society and the country (Kementerian Pendidikan Malaysia, 2013).

Nevertheless, not all private preschools in Malaysia have fully adopted the NPSC. These preschools are usually franchisees of local and international programs brought into Malaysia. Examples are the Montessori, British, Australian, or Canadian and locally developed religionbased programs. Besides, the international preschools often encourage children to pursue primary education in same institution.

From the overall number of preschools providing services to children aged five to six years in Malaysia, 40\% are privately owned and operated (Foong, Veloo, Dhamotharan, \& Loh, 2018 ). The reasons are that the private preschools in Malaysia are generally better equipped, offer a different and exciting curriculum, have more staff, and accommodate more children than the public preschool. This shows that preschools' curriculum and program are essential aspects of parents' consideration for their children's choice of a preschool (Qin \& Nor, 2018).

\section{CURRENT CHALLENGES IN ECCE}

Many of the challenges faced in the ECCE field in Malaysia would bore some resemblance to the ECCE community's problems worldwide. These challenges usually revolve around the curriculum and standards, professionalism, policies, funding, infrastructure, and stakeholders' involvement. Therefore, the following challenges of ECCE in Malaysia were identified and discussed according to the emerging themes below:

\section{Curriculum related issues}

Ideally, all early childhood programs should adopt a research-based curriculum that is developmentally, culturally, socially, emotionally, and linguistically appropriate for all children. However, in the age of technological advancement and globalization, there are a plethora of demands from stakeholders and aspects to be considered in an ECCE curriculum development. Hence, the curriculum is continuously enhanced to support children's development in becoming a contributing future citizen. There is also, a concern in curriculum implementation to capacitate children's total and holistic development including sports, science, technology, arts, while at the same time encouraging good personality development. While parents and educators argued 
that preschool education should not focus too much on academic learning, they are however still overly concerned about making sure that their children can read, write and compute before entering primary schooling (Majzub, 2013; Puteh \& Ali, 2013). Parents are also increasingly concerned about their children's need to be multilingual to be viewed as a future global player (Ismail, Anis, Subramaniam, Amiruddin, \& Ismail, 2018; Majzub \& Rashid, 2012).

Another disquieting aspect is the curriculum's continuity and children's transition between nursery into preschool and henceforth into primary schooling. Currently, there seems to be a problem of integrating and interfacing between the early childhood and the primary schooling curriculum (Kasim, 2014; Poh \& Chu, 1984).

Teachers' understanding of the curriculum affects the success of children's learning. Therefore, teachers' knowledge of the curriculum is considered crucial because it indicates the specific contexts of learning and other aspects of curriculum implementation. However, Malaysian preschool teachers faced several difficulties (Chee, Mariani, MR, Kadir, \& Salim, 2015; Masnan, Sharif, \& Josin, 2018). Among the main problems identified include the lack of understanding of the curriculum requirements and needs, concept and principles of ECCE, lack of passion, genuine inner drive to acquire knowledge and to implement it in the provision of children's learning (Rahman \& Noor, 2018).

\section{Workforce and teacher training}

A fundamental issue is related to the lack of training that leads to inadequate knowledge about implementing the curriculum in childcare and preschool centers. This certainly impacts the children's learning experiences throughout the early years and preparation for school-readiness in later years (Che Mustafa et al., 2019; Hanafi, 2015). Besides, there are features or requirements included in the curriculum, such as integrating thematic thinking and learning skills, were not effectively implemented. Some teachers also did not practice appropriate strategies such as playbased learning and integrated approaches (Chee et al., 2015).

Contrary to the philosophies of play based learning in ECCE, several studies pointed out that teachers are still using traditional teacher-centered approaches. These teachers believe that it is the most appropriate method to reinforce pupils' understanding of memory and skills, especially literacy and numeracy skills. They often use coercive techniques, drills, and memorization for skills and knowledge acquisition. Furthermore, the teachers believe that this approach meets the demands of schools and parents requiring children to master reading, writing, and arithmetic upon entering formal education (Chee et al., 2015; Qin \& Nor, 2018).

Other than teachers' knowledge, the ratio of teacher to children is also a concern in ECCE, wherein private preschools maintain a ratio of normally 1:14 while the ratio in public preschools can be 1:22. On the other hand, the average number of children in a public preschool is 28 while it is possible to take in 61 children in the private sector depending on the size of the premise and facilities available (Kementerian Pendidikan Malaysia, 2013). These are the government's guidelines related to teacher-child ratio and number of children enrolled in the public and private preschools. However, there are instances whereby the actual distribution of teachers on the ground is different whenever there is shortage and hence becomes an issue mainly in the private childcare centers and preschools. Until today, the shortage of teachers is still one of the main hurdles in Malaysian ECCE (Mohidin, Ismail, \& Ramli, 2015). 
Besides the lack of academic qualification, continuous training in the form of professional development programs for teachers posed another obstacle in changing current practices. These teachers only knew and implement a prescriptive approach, using workbooks, activity sheets, and frequent testing, with lack of opportunities for play-based activities. Another essential aspect in ECCE is to discern and employ appropriate assessment instruments in providing teachers and parents important milestones to meet the needs and support children's growth and development. Hence, by laying out the fundamentals of curriculum and assessment for the teachers to start with, they need to be encouraged and supported to change their existing practice towards more developmentally and culturally appropriate approaches (F. Yunus, 2017)

The most difficult part of the change process is to transform the social environment by reducing the amount of direct instruction among teachers. This situation was rooted in the social-cultural context where the teachers grew up or lived. Culturally speaking, the Malay ethnics tend to obey adults most of the time, and it is considered rude when young people decline. Moreover, it is believed to be a sinful act for Malay-Muslims to disobey adults. Nonetheless, some Muslim scholars believe that children should be treated otherwise they must be loved with tenderness. As a result of the circumstances mentioned, teachers tend to be autocratic when they are at preschool simply because they choose to believe the former teachings (F. Yunus, 2017).

The journey to change practices can be an emotional experience with peaks and troughs for the individuals involved. Changing the mindset of practitioners take more than just a series of lecture-based training. In ensuring change, teachers must be given constant guidance and reminders, while trainers needed to be around to address questions and lend their support. The lack of knowledge and skills mentioned earlier are challenges that can potentially be overcome through continuous professional development. The problem is also contributed by lack of funding, resulting from low-fees charged by childcare centers - caused by the perceptions of many individuals who think that education for young children is trivial.

\section{Physical environment and accessibility}

Health is not merely the absence of disease or ailment but a state of complete physical, mental, and social well-being. Healthy children will become healthy adults, and as such, it is vital to identify factors that influence health from the beginning of life, i.e., during the prenatal period and throughout the early years. A child's health outcomes are determined by the interaction of many determinants, including biological, prenatal, perinatal, and postnatal events, behavioral influences such as emotions, beliefs, attitudes, and cognitive abilities. Besides, the physical and social environment can also have profound effects on a child's physical and mental health outcomes. This includes factors such as interaction with family members and peer relationship health, the environment the child lives in, education level, and socio-economic status of his/her family, and cultural practices of the family and community.

In addition, the environmental factors associated with the nutritional status of children include completion of immunization programs, and health-seeking behavior which in turn influences the health and well-being of the child. Studies for instance, showed that adverse social exposures in childhood might lead to chronic disorders later in life (Crandall et al., 2019; Felitti et al., 2019; Flaherty et al., 2013). The various contributing factors discussed so far can also influence and impact Malaysian children's health and well-being. This is due to the fact that 
although Malaysia is considered as an upper-middle-income country with diverse ethnics and multicultural, a significant percentage of the population are still in the lower income group known as the B40 which are prone to be deprived of the optimal condition needed for a child's development (Shahar, Lau, Puteh, Amara, \& Razak, 2019). Moreover, the research into the impact of biological, environment, and physical factors discussed above is still scanty both in terms of short term and longitudinal studies. Such studies are significant in collecting evidence for decision making and formulating policies processes related to Malaysian ECCE.

The psychological research in this field indicated that children's development and their behaviors are also affected by the physical design of the environment in childcare centers (Sahimi \& Said, 2012; Shaari \& Ahmad, 2016). Indisputably, local authorities throughout the country provide guidelines for designing childcare centers' physical environment, but are limited to general aspects and explanations (Nik Azhari, Qamaruzaman, Ibrahim Bajunid, \& Hassan, 2015). Besides, in order to provide and maintain these physical facilities and environment, it will require a considerable amount and extensive funding from providers. Hence, financial constraint is among the biggest challenges in Malaysian ECCE in public and private centers (Shaari \& Ahmad, 2016).

\section{Parental and community involvement}

Parents are regarded as both the first teacher and partners in educating their children despite the fact, that many are not equipped with parenting knowledge to nurture children. These days, parents are too occupied with their jobs and have little time to attend to their children's education (Abd Raof et al., 2020). It is notable that not all childcare centers are able to educate parents on the curriculum and programs. This was found to be limited to urban preschools which included parental education programs in their curriculum (Majzub, 2003). Moreover, many parents still possess the notion that childcare is equivalent to custodial care. On the basis of these grounds therefore, there ought to be an awareness campaigns to advise parents, especially parents in the lower socio-economic group, of the grave consequences if their children's formative years are not given appropriate developmental experiences. Not only are parents the first and foremost caregiver and educator of children's formative years, they are also members of society who can compel the government in making quality childcare accessible to their children.

Lack of good parenting is often blamed for children's misbehavior. This is a recurrent theme, notably with children from disadvantaged families often exposed to multiple adversities (e.g., community violence, poverty). Often, these parents are employed in multiple jobs and do not have enough time to attend to their children's needs. As a result, many of these children are at risk in terms of social and behavioral delays, childhood anxiety, and mental development.

Collaboration and engagement between childcare centers and the local community can take on a variety of forms and interpretations. Depending on the child's developmental stage and the viewpoints taken on the problem from teachers, parents, and researchers, significant benefits for children, families, practitioners, center, and the community can be accomplished. Moreover, there is a rich amount of expertise and resources available yet untapped by childcare centers for the benefit of their children's learning. Among private ECCE centers, the involvement revolves around offering their centers for pre-service teachers to perform teaching practice or practicum. However, in terms of involvement with the local communities and childcare centers, the 
activities are mostly confined to organized annual visits to the Fire and Rescue Department, local government clinics or dental clinics as part of children's learning activities. Generally, childcare centers indicate reluctance to involve the local community, with the exception, for compulsory monitoring activities conducted by the related government agencies as required by law. In short, childcare centers need to be creative and proactive in moving beyond current practices in utilizing the existing community resources and expertise (Rahmatullah et al., 2020).

\section{IMPLICATIONS AND FUTURE DIRECTIONS}

In recent years, attempts have been made to enhance the quality of ECCE considering that the younger generation will be the nation's future leaders. Efforts to develop policies, rules, and regulations for the early-years, had for some time started in many parts of the world. Similarly, Malaysia has also played its part in ensuring that every child has the same opportunity to grow up in a holistic manner (Boon, 2010; F. Yunus, 2017). In Malaysia, the current acts, policies, and guidelines are believed to cover all aspects of children's cognitive, social and emotional development including the psychological effect of the physical environment in childcare centers (Nik Azhari et al., 2015).

Numerous ECCE stakeholders, including the MOE, have always been ardent on charting the ECCE progress and are committed to more significant advancement for a comprehensive and integrated ECCE curriculum, and programs. Hence, with substantial commitment and collaboration from stakeholders, the future of the Malaysian ECCE can be further improved and strengthened.

The curriculum of the Malaysian ECCE embraces a huge emphasis on experiential learning and making a significant impact on children's development through genuine learning by doing (Ahmad, Baharom, Yahaya, Shamsiah, \& Sani, 2018; Ismail et al., 2018; Rahman \& Noor, 2018). Apart from that, a substantial focus on appropriately supporting children through learning opportunities that will strengthen their self-confidence and self-esteem will be valuable to support them develop into happy, well-adjusted individuals (Saniei Abadeh \& Abedi, 2019; Siew \& Nor, 2019). At the same time, children should be afforded sufficient attention and learning opportunities based on their unique abilities, allowed to grow according to individual pace, and increase their self-confidence (Adnan et al., 2017).

The Malaysian ECCE also endeavors to garner the benefits of creativity by integrating the learning activities with a comprehensive range of essential future skills such as problem solving, critical thinking, collaboration, leadership, and communication (Husaini, Ikhsan, \& Toran, 2019; F. W. Yunus, 2019). The childcare centers also implement innovative programs allowing opportunities for children to explore new areas such as drama, science, technology, music, performances and presentations, arts, and more (Ahmad et al., 2018; Hassan, Abdullah, Ismail, Suhud, \& Hamzah, 2019). The steps taken will nurture and cultivate mature children that are equipped with the abilities needed to excel academically and contribute to society.

The realization of the future directions for the Malaysian ECCE depend on an enduring partnership between stakeholders which include childcare centers, governments, educators, and parents. The collaboration of all the stakeholders, combined with initiatives provided by the government should improve and raise the quality of the Malaysian ECCE. With continuous support by the government for the Malaysian ECCE through acts, standards, and policies that 
were developed comprehensively and implemented so far, ECCE in Malaysia remains to be recognized as experiencing a promising growth (Kementerian Pendidikan Malaysia, 2013).

The Malaysian government also plans to continuously improve the quality of education in the country. The government have progressively engaged multiple stakeholders in ongoing discussions and detailed planning to resolve ECCE related issues and challenges in collaboration with the public and private sectors. A particular recent initiative in improving the quality and standards of ECCE in Malaysia is envisaging that $100 \%$ of educators in early years have minimum qualifications, which will successively raise the standards of ECCE programs at nursery and preschool levels.

Indeed, while the aspirations of the Education Blueprint of Malaysia 2013-2025 can be saluted as the driving and motivating force, the transformation ideals cannot be achieved, or discrepancies narrowed without a proper plan of action in the ECCE scenario. The policymakers, practitioners, community, and ECCE experts at all levels should collaborate to address fundamental ECCE issues in Malaysia mentioned in this article.

Additionally, conversations on quality programs require consistent emphasize that include parental involvement and a robust, psychologically safe, and healthy environment. Although parental involvement is generally thought to be beneficial for children, it is unclear whether intensive parenting levels would improve outcomes for children. Hence, there is a need to assess parenting beliefs that ensure children's health, happiness, and success and to identify the impact of positive parenting practices that foment children's differential learning trajectories. Investigations undertaken on parenting also include the relationship between specific practices onto reported risks of developmental, behavioral, or social delays among children. Further to this, examples of parenting practices studied include cognitively stimulating activities, limit-setting, disciplinary practices, reading to children, engaging in storytelling or singing, eating meals together, parent warmth, or combining these parenting practices and their effect on children's outcomes.

\section{CONCLUSION}

Researchers have long acknowledged that the early years of a child's life as imperative to their developmental years. Accordingly, ECCE is the predominant cornerstone of our entire educational system. Therefore, it is of utmost importance to provide and support the establishment of a quality ECCE program to ensure that all children are appropriately nurtured in their early years. Consequently, all stakeholders, especially the authorities from government agencies and institutions, need to take bold actions to make ECCE universally accessible to children of all backgrounds, regardless of their ethnic, economic, or social status. Also, there needs to be continuous monitoring and support for the emergence of nurseries and preschools to help deliver the best quality services in every public or private early year's institution. Quality services will ultimately lead to quality care and education for each child.

Before formal schooling, quality care and education for young children is crucial because it affects positive long-term growth such as reducing school dropout, delayed development, and juvenile delinquencies. The United States of America for instance, is among the few nations that measure ECE quality from the economic perspectives, as reported in the Barnett and Ackerman (2006) study. Nonetheless, there are also suggestions that quality in ECE should be considered apart from economic measures, and instead, children need to be allowed to become the coconstructor of identity, culture, and knowledge (Haslip \& Gullo, 2018; Moss \& Dahlberg, 2008). 
This is widely known as the post-modernist view that emphasizes the democratic approach and emergent curriculum and learning, as in the Reggio Emilia approach (Sunday \& Conley, 2020).

ECCE remains a fundamental establishment in society because a conducive and an enabling environment will augment favorable developments of its young generation and, thus, a more harmonious society for the future. Furthermore, whenever children spend less time than they ought to with family members due to various socio-economic factors, in that case, nurseries and preschools play significant roles to foster the development processes.

This paper is intended to provide an overview of the current context of ECCE in Malaysia. The aim is to provide the background and landscape of Malaysian ECCE, highlight policies and acts governing the establishments besides the standards and curriculum of childhood care and education. An additional purpose is to provide insights for others in recognizing the issues and challenges and coming up with ways to improve the quality of childcare and education. Other than that, based on the discussions in this paper, extensive studies are necessary to be carried out so that the development of policies on ECCE, establishment of ECCE related services, and training of practitioners are in accordance with the needs of children in their vulnerable years for the fulfillment of their existing potentials.

\section{REFERENCES}

Abd Raof, N., Ishak, M. S., Mohamad, M. S., Ali, M. A. Z., \& Ibrahim, A. Z. (2020). Tahap Penglibatan Ibu Bapa Dalam Didikan Kanak-kanak di TASKA KEMAS (Stage of Parental Involvement In Early Childhood Education at TASKA KEMAS). Jurnal Kesidang, 5(1).

Adnan, M., Ayob, A., Tek, O. E., Ibrahim, M. N., Ishak, N., \& Sheriff, J. (2017). Memperkasa pembangunan modal insan Malaysia di peringkat kanakkanak: Kajian kebolehlaksanaan dan kebolehintegrasian pendidikan STEM dalam kurikulum PERMATA Negara (Enhancing Malaysian human capital from early childhood: A study in the feasibility and inte. Geografia-Malaysian Journal of Society and Space, 12(1).

Ahmad, C. N. C., Baharom, S., Yahaya, A., Shamsiah, S., \& Sani, H. A. (2018). The development of 'Jom Teroka dan Selidik Sains' teaching module. International Journal of Academic Research in Business and Social Sciences, 8(1), 705-715.

Ayob, A. (2011). Laporan pemantauan \& pengawalseliaan program PERMATA Negara 2010. Tanjung Malim: Universiti Pendidikan Sultan Idris (UPSI).

Bahagian Pembangunan Kurikulum. (2017). Dokumen standard Kurikulum dan Pentaksiran KSPK 2017. Kementerian Pendidikan Malaysia.

Bahagian PERMATA. (2013). Kurikulum PERMATA Negara: Asuhan dan Didikan Awal Kanak-kanak 0-4 Tahun Cetakan Ketiga. Bahagian Pendidikan Awal Kanak-kanak Jabatan Perdana Menteri Malaysia.

Barnett, W. S., \& Ackerman, D. J. (2006). Costs, benefits, and long-term effects of early care and education programs: Recommendations and cautions for community developers. Community Development, 37(2), 86-100.

Berlinski, S., Galiani, S., \& Gertler, P. (2009). The effect of pre-primary education on primary school performance. Journal of Public Economics, 93(1-2), 219-234.

Berlinski, S., Galiani, S., \& Manacorda, M. (2008). Giving children a better start: Preschool attendance and school-age profiles. Journal of Public Economics, 92(5), 1416-1440. https://doi.org/https://doi.org/10. 1016/j.jpubeco.2007.10.007. 
Black, M. M., Walker, S. P., Fernald, L. C. H., Andersen, C. T., DiGirolamo, A. M., Lu, C., .. GranthamMcGregor, S. (2017). Early childhood development coming of age: Science through the life course. The Lancet, 389(10064), 77-90. https://doi.org/10.1016/S0140-6736(16)31389-7.

Boon, N. S. (2010). Governance of education related ECCE policies in Malaysia. International Journal of Child Care and Education Policy, 4(1), 45-57.

Center on the Developing Child. (2007). A science-based framework for early childhood policy: Using evidence to improve outcomes in learning, behavior, and health for vulnerable children. Center on the Developing Child, Harvard University.

Che Mustafa, M., Kung-Teck, Wong Norazilawati, A., Rahmatullah, B., Omar, J., Mohammad Samuri, S., \& Md Yasin, S. (2019). Educationists voice on quality early childhood care and education in Malaysia. International Journal of Innovation, Creativity and Change, 10(8).

Chee, J., Mariani, M. N., MR, N. M., Kadir, A., \& Salim, S. N. (2015). The preschool curriculum implementation versus problems. Southeast Asia Early Childhood Journal, 4, 31-42.

Chiam, H. K. (2008). Child care in Malaysia: Then and now. International Journal of Child Care and Education Policy, 2(2), 31-41.

Crandall, A., Miller, J. R., Cheung, A., Novilla, L. K., Glade, R., Novilla, M. L. B., . . Hanson, C. L. (2019). ACEs and counter-ACEs: How positive and negative childhood experiences influence adult health. Child Abuse \& Neglect, 96, 104089. https://doi.org/https://doi.org/10.1016/j.chiabu.2019.104089.

Felfe, C., \& Lalive, R. (2018). Does early child care affect children's development? Journal of Public Economics, 159, 33-53.

Felitti, V. J., Anda, R. F., Nordenberg, D., Williamson, D. F., Spitz, A. M., Edwards, V., .. Marks, J. S. (2019). Reprint OF: Relationship of childhood abuse and household dysfunction to many of the leading causes of death in adults: The adverse childhood experiences (ACE) study. American Journal of Preventive Medicine, 56(6), 774-786. https://doi.org/10.1016/j.amepre.2019.04.001.

Flaherty, E. G., Thompson, R., Dubowitz, H., Harvey, E. M., English, D. J., Proctor, L. J., \& Runyan, D. K. (2013). Adverse childhood experiences and child health in early adolescence. JAMA Pediatrics, 167(7), 622-629. https://doi.org/10.1001/jamapediatrics.2013.22.

Foong, L., Veloo, P. K., Dhamotharan, M., \& Loh, C. (2018). Private sector ealy child care and education in Malaysia: Workforce readiness for further education. Kajian Malaysia: Journal of Malaysian Studies, $36(1)$.

Hanafi, Z. (2015). The childcare center: How to ensure quality childcare practices. Asian Social Science, 11(25), 90-100.

Haslip, M. J., \& Gullo, D. F. (2018). The changing landscape of early childhood education: Implications for policy and practice. Early Childhood Education Journal, 46(3), 249-264.

Hassan, M. N., Abdullah, A. H., Ismail, N., Suhud, S. N. A., \& Hamzah, M. H. (2019). Mathematics curriculum framework for early childhood education based on science, technology, engineering and mathematics (STEM). International Electronic Journal of Mathematics Education, 14(1), 15-31.

Havnes, T., \& Mogstad, M. (2011). No child left behind: Subsidized child care and children's long-run outcomes. American Economic Journal: Economic Policy, 3(2), 97-129. https://doi.org/10.1257/pol.3.2. 97.

Heckman, J. J., Stixrud, J., \& Urzua, S. (2006). The effects of cognitive and noncognitive abilities on labor market outcomes and social behavior. Journal of Labor Economics, 24(3), 411-482.

Husaini, R., Ikhsan, Z., \& Toran, H. (2019). A comprehensive 21st century child development through scientific process in early science. Creative Education, 10(12), 2784.

Hussin, S. (1993). Pendidikan di Malaysia: Sejarah, sistem dan falsafah. Dewan Bahasa dan Pustaka. 
Imran, A. A., Faizul, A. K., Khadijah, I., Rizawati, A. H., \& Wan, Z. W. A. (2010). Kajian-kajian lepas berkaitan pendidikan awal kanak-kanak di peringkat tadika atau pra sekolah. Universiti Pendidikan Sultan Idris, 20.

Institut Pendidikan Guru Malaysia. (2018). Modul Pendidikan Awal Kanak-kanak (PAKKD2033 Pengajaran dan Pembelajaran dalam Pendidikan Awal Kanak-kanak). In MODUL PENDIDIKAN AWAL KANAK-KANAK.

Ismail, I. M., Anis, S. K., Subramaniam, T. S., Amiruddin, H., \& Ismail, M. E. (2018). Penerapan elemen perkembangan kognitif, psikomotor dan sosio-emosi dalam permainan dalam mencapai objektif Kurikulum Standard Prasekolah Kebangsaan. Online Journal for TVET Practitioners, 1.

Kasim, N. (2014). Penilaian program transformasi pendidikan prasekolah KPM di sekolah kebangsaan. UKM.

Kementerian Pendidikan Malaysia. (2013). Pelan pembangunan pendidikan Malaysia 2013-2025. Putrajaya: Kementerian Pendidikan Malaysia.

Kosnin, A. M., Rameli, M. R. M., Jiar, Y. K., Ashari, Z. M., Siah, L. M., \& Daud, M. Z. (2018). Acceptance and implementation of the national PERMATA Programme in Malaysian government-run early childhood centres. Advanced Science Letters, 24(5), 3636-3640.

Majzub, R. M. (2003). Pendidikan prasekolah: Cabaran kualiti. Penerbit Universiti Kebangsaan Malaysia.

Majzub, R. M. (2013). Critical issues in preschool education in Malaysia. Proceedings of the 4th International Conference on Education and Educational Technologies (EET'13), 150-155.

Majzub, R. M., \& Rashid, A. A. (2012). School readiness among preschool children. Procedia-Social and Behavioral Sciences, 46, 3524-3529.

Mamat, N. (2019). Children's experience and learning opportunities in PERPADUAN (unity) pre-school settings in Malaysia. International Conference Primary Education Research Pivotal Literature and Research UNNES 2018 (IC PEOPLE UNNES 2018). Atlantis Press.

Masnan, A. H., Sharif, M. H., \& Mohd Josin, E. H. (2018). Preschool Teachers' Professionalism Through Developmentally Appropriate Practices (DAP) Curriculum. Journal of Social Science and Humanities, $1(5), 20-25$.

Mofrad, S. (2012). Opportunity in early childhood education: Improving interaction and communication. Procedia-Social and Behavioral Sciences, 46, 241-246.

Mohidin, H. H. B., Ismail, A. S., \& Ramli, H. B. (2015). Effectiveness of kindergarten design in Malaysia. Procedia-Social and Behavioral Sciences, 202, 47-57.

Moss, P., \& Dahlberg, G. (2008). Beyond quality in early childhood education and care: Languages of evaluation. New Zealand Journal of Teachers' Work, 5(1), 3-12.

Murnane, R. J., \& Ganimian, A. (2014). Improving educational outcomes in developing countries: Lessons from rigorous impact evaluations. NBER Working Paper, (w20284).

Mustafa, L. M., \& Azman, M. N. A. (2013). Preschool education in Malaysia: Emerging trends and implications for the future. American Journal of Economics, 3(6), 347-351.

Nik Azhari, N. F., Qamaruzaman, N., Ibrahim Bajunid, A. F., \& Hassan, A. (2015). The quality of physical environment in workplace childcare centers. Procedia-Social and Behavioral Sciences, 202, 15-23.

Poh, L. C., \& Chu, L. (1984). Pre-school curriculum and the total development of the child in Malaysia. The Asia Pacific Journal of Educators and Education, 6.

Pope, J. (2017). Beyond basic 'minding': Adopting an ecological, evidence based approach to promoting children's well-being and developing child health advocacy with early childhood undergraduate students (Pre-published version). 
Puteh, S. N., \& Ali, A. (2013). Belajar melalui bermain: Prinsip utama kurikulum pendidikan awal kanakkanak. Utusan Publications \& Distributors.

Qin, T. Y., \& Nor, M. M. (2018). Exploring issues on teaching and learning in Malaysian Private Preschools. MOJEM: Malaysian Online Journal of Educational Management, 6(2), 67-82.

Rahman, M. N. A., \& Noor, W. N. B. W. M. (2018). Pelaksanaan Kurikulum standard Prasekolah Kebangsaan semakan 2017: Retrospeksi guru. JuPiDi: Jurnal Kepimpinan Pendidikan, 5(3), 59-71.

Rahmatullah, B., Yassin, S. M., \& Omar, J. (2020). Local community involvement in Malaysian early childhood care and education centers. International Journal of Educational Management, 35(1), 143-157. https://doi.org/10.1108/IJEM-05-2020-0259.

Sahimi, N. N., \& Said, I. (2012). Young children selections of the physical elements in the preschool environment. Procedia-Social and Behavioral Sciences, 38, 176-183.

Saniei Abadeh, S., \& Abedi, A. (2019). The effectiveness of quinn's early childhood education program on the self-esteem of preschool children. Quarterly Journal of Child Mental Health, 6(2), 160-169.

Shaari, M. F., \& Ahmad, S. S. (2016). Physical learning environment: Impact on children school readiness in Malaysian preschools. Procedia-Social and Behavioral Sciences, 222, 9-18.

Shahar, S., Lau, H., Puteh, S. E. W., Amara, S., \& Razak, N. A. (2019). Health, access and nutritional issues among low-income population in Malaysia: Introductory note. BMC Public Health, 19(4), 552. https:// doi.org/10.1186/s12889-019-6852-8.

Shonkoff, J. P., \& Phillips, D. A. (2000). From neurons to neighborhoods: The science of early childhood development. In J. P. Shonkoff, \& D. A. Phillips (Eds.), From neurons to neighborhoods: The science of early childhood development. Washington, DC, US: National Academy Press.

Siew, S. K., \& Nor, M. B. M. (2019). Supporting preschool children's early writing with self-regulated learning strategies. Asia-Pacific Journal of Research in Early Childhood Education, 13(2).

Sunday, K., \& Conley, K. (2020). Drawing at the center of an emergent preschool curriculum. Art Education, 73(6), 18-23.

The Commissioner of Law Revision Malaysia (1984). Act 308 child care Centre Act 1984 (Incorporating all amendments up to 1 January 2006). Malaysia.

UNESCO, E. (2007). EFA Global Monitoring Report 2007. Strong foundations. Early childhood care and education. 2/1/UNESCO/R/07/E.

United Nations Committee on the Rights of the Child. (2005). General Comment No. 7: Implementing child rights in early childhood. UN Doc CRC/GC/2005/7, Para, 11.

Yunus, F. (2017). Changing curriculum practice in early childhood education setting: An action research to enhance authentic assessment. Advances in Social Sciences Research Journal, 4(11).

Yunus, F. W. (2019). Practitioners' views on learning using children's peer interactions amongst under three year old children in Selangor, Malaysia. Asian Journal of University Education, 15(3), 54-68.

Open Access. This is an open-access article distributed under the terms of the Creative Commons Attribution-NonCommercial 4.0 International License (https://creativecommons.org/licenses/by-nc/4.0/), which permits unrestricted use, distribution, and reproduction in any medium for non-commercial purposes, provided the original author and source are credited, a link to the CC License is provided, and changes - if any - are indicated. 